\title{
Gestational Trophoblastic Neoplasm cM1 TNM Finding v8
}

National Cancer Institute

\section{Source}

National Cancer Institute. Gestational Trophoblastic Neoplasm CM1 TNM Finding v8. NCI

Thesaurus. Code C140019.

Gestational trophoblastic neoplasm with distant metastasis. (from AJCC 8th Ed.) 